Article

\title{
An Analysis of Electricity Consumption Patterns in the Water and Wastewater Sectors in South East England, UK
}

\author{
Aman Majid ${ }^{1,2, * \mathbb{C}}$, Iliana Cardenes ${ }^{1,+} \mathbb{( D}$, Conrad Zorn $\left.{ }^{1, \ddagger} \mathbb{(}\right)$, Tom Russell ${ }^{1} \mathbb{D}$, Keith Colquhoun $^{3}$, \\ René Bañares-Alcantara ${ }^{2}$ and Jim W. Hall ${ }^{1}$ (D) \\ 1 Environmental Change Institute, University of Oxford, Oxford OX1 2JD, UK; \\ ilianacardenes@gmail.com (I.C.); conrad.zorn@auckland.ac.nz (C.Z.); tom.russell@ouce.ox.ac.uk (T.R.); \\ jim.hall@ouce.ox.ac.uk (J.W.H.) \\ 2 Department of Engineering Science, University of Oxford, Oxford OX1 2JD, UK; rene.banares@eng.ox.ac.uk \\ 3 Thames Water Utilities Ltd., Reading RG2 0BY, UK; keith.colquhoun@thameswater.co.uk \\ * Correspondence: aman.majid@new.ox.ac.uk; Tel.: +186-528-5070 \\ + Current affiliation: Department for Business, Energy, and Industrial Strategy, London SW1H 0ET, UK. \\ $\ddagger$ Current affiliation: Department of Civil and Environmental Engineering, University of Auckland, \\ Auckland 1010, New Zealand.
}

Received: 26 November 2019; Accepted: 7 January 2020; Published: 14 January 2020

\begin{abstract}
The water and wastewater sectors of England and Wales $(E \& W)$ are energy-intensive. Although E\&W's water sector is of international interest, in particular due to the early experience with privatisation, for the time being, few published data on energy usage exist. We analysed telemetry energy-use data from Thames Water Utilities Ltd. (TWUL), the largest water and wastewater company in the UK, which serves one of the largest mega-cities in the world, London. In our analysis, we: (1) break down energy use into their components; (2) present a statistical approach to handling seasonal and random cycles in data; and (3) derive energy-intensity $\left(\mathrm{kWh} \mathrm{m}^{-3}\right)$ metrics and compare them with other regions in the world. We show that electricity use in the sector grew by around $10.8 \pm 0.4 \%$ year $^{-1}$ as the utility coped with growing demands and stormwater flooding. The energy-intensity of water services in each of the utility's service zone was measured in the range $0.46-0.92 \mathrm{kWh} \mathrm{m}^{-3}$. Plans to improve the efficiency of the system could yield benefits in lower energy-intensity, but the overall energy saving would be temporary as external pressures from population and climate change are driving up water and energy use.
\end{abstract}

Keywords: water-energy nexus; energy use; energy intensity

\section{Introduction}

Water and wastewater systems in England and Wales (E\&W) are highly energy-intensive, a topic that has attracted increasing attention over the last decade or so. Driven by the rising cost of electricity, as well as the greenhouse gas footprint associated with energy use, the sector has recognised energy as a significant operational cost that needs to be managed. For instance, all water supply companies in E\&W are currently working towards achieving a voluntary target to reduce operational greenhouse gas emissions to net-zero by 2030 [1]. However, despite the rapidly changing landscape of energy-use in the water and wastewater sectors of E\&W, few studies focusing on the region exist in the literature. This study aims to contribute novel data and information from E\&W to an already well-developed and international body of literature focusing on understanding the energy-influence of water and wastewater systems. 
Energy use in the water and wastewater sectors can be divided into two separate categories: (1) electricity used in industry; and (2) electricity used by household and non-household consumers for water-related provisions. Since the characteristics of water systems differ hugely between regions based on the local water demands, climate and geography, the amount of electricity needed in each function within the supply chain can be significantly different between regions [2]. In the first category of water-related energy use, electricity is needed throughout a complex network of water and wastewater operations, which include water abstraction, distribution, treatment, sewage transportation and wastewater treatment [3]. The energy required for abstraction depends on whether the source is ground water or surface water [4]. Energy use in ground water abstraction is linear to the amount of lift $(\mathrm{m})$ that must be overcome to raise water, where the mean energy-intensity has previously been approximated as $0.004 \mathrm{kWh} \mathrm{m}^{-3} \mathrm{~m}^{-1}$ [5]. In surface water abstraction, electricity use mainly depends on the conveyance distance and the local elevation profile, which has been estimated as $0.002-0.007 \mathrm{kWh} \mathrm{m}^{-3} \mathrm{~km}^{-1}$ using data from Spain, Australia and the United States [5]. Water treatment plant operations such as filtration, oxidation and ultraviolet treatment comprise the major component of the energy demand at water treatment facilities [6]. The energy requirements for these processes are again dependent on the local system, where factors such as the raw water quality and demand can dictate the unit operations needed. For instance, Plappally and Leinhard [5] reported energy intensities associated with conventional water treatment methods of $0.01-0.20,0.18-0.47$ and $0.38-1.44 \mathrm{kWh} \mathrm{m}^{-3}$ in Australia, United States and Canada, respectively, despite the countries having similar treatment standards on the water supplied. Desalination, which is a highly energy-intensive water treatment process, is also being increasingly used across the world, including in E\&W [7]. The method employed in E\&W involves desalting brackish water using Reverse Osmosis (RO), which has a reported energy-intensity of $1.0-2.5 \mathrm{kWh} \mathrm{m}^{-3}$ [8] that is comparatively lower than other methods such as RO of seawater $\left(2.5-7.0 \mathrm{kWh} \mathrm{m}^{-3}\right)$ and multistage flash distillation $\left(2.5-7.0 \mathrm{kWh} \mathrm{m}^{-3}\right)$ [9]. Recent advancements in desalination have decreased the energy requirements of the process [7] but it remains highly energy-intensive when compared with conventional treatment, and its future use is expected to grow in E\&W and beyond. Once water has been used by household and non-household consumers, the wastewater generated must be treated to remove pollutants before it is released back into the environment. Substantial amounts of energy can be consumed by unit operations such as sludge pumping in primary treatment $\left(0.04-0.19 \mathrm{kWh} \mathrm{m}^{-3}\right)$ and aeration in secondary treatment $\left(0.02-0.13 \mathrm{kWh} \mathrm{m}^{-3}\right)$ [5]. The main driver for energy use in wastewater treatment is not only the location but also the size of the plant, the types and levels of operational techniques employed, effluent input and output quality and experience of the operations staff [10]. In the second category of water-related energy use, water users require significant inputs of electricity, mainly for water cooling and heating. This is usually the most energy-intensive portion of the whole water supply chain. For example, Siddiqi and de Weck [11] reported urban end use energy use of $3.16 \mathrm{kWh} \mathrm{m}^{-3}$ in San Diego, U.S., which was almost double the energy-intensity of the supply and treatment system. Data on the energy-intensiveness of the water and wastewater supply chain in E\&W are extremely scarce.

There are 19 privately-owned water and wastewater or water-only utility companies in E\&W that reportedly consume around $2-3 \%$ of the overall national energy supply [12]. This makes the sector the fourth most energy-intensive industry [13]. In the water sector, electricity use was observed to have increased by over 10\% in the eight years between 2002 and 2010 [14], likely driven by changing water quality standards given the amount of water supplied remained largely the same. In response, water managers have acted quickly to manage energy costs. Operational assets are being optimised and upgraded to better manage energy demands [13]. Meanwhile, several utilities in E\&W have already installed solar Photovoltaics (PVs) and wind turbines on-site, and many are also generating bio-gas from sewage sludge at wastewater treatment plants. As an example, two of the largest water and wastewater utilities, Thames Water Utilities Ltd. and United Utilities, self-generated 22\% and $21 \%$ of their total electricity consumption, respectively $[15,16]$. The self-generation capacity is only expected to grow. For instance, analysis from the water regulator in E\&W, Ofwat, suggests 
that energy-from-sludge schemes can be expanded and optimised to realise $£ 1$ billion of benefits for customers [17]. Reductions in per capita demand for water and leakages are being targeted across E\&W. Although these are generally classified as water demand strategies, these schemes will yield a co-benefit of lowered energy use as it decreases the requirements on pumping and treatment systems [18-20]. However, the benefits would diminish in time if the overall population increases.

There is, therefore, a clear momentum to better understand and control electricity use in the water and wastewater industries of E\&W. However, for the moment the scientific literature is lacking, in that there are few published data or regional scale case-studies reporting the influence of water-related electricity use in the sectors of E\&W. As studies from other parts of the world have shown, local case-studies on water-related electricity can form a vital pre-requisite in designing energy reduction policies for the sector in terms of their cost-effectiveness and efficacy [21-23]. For example, in California, research on water-related energy use, such as that of Klein et al. [24] from the California Energy Commission, as well as the studies that proceeded, led to policy-driven action to reduce electricity use in the water sector. Reductions of around 1830 GWh in 2-3 years were reported, which was mainly achieved by managing water demands [20]. However, as the literature evolved, Kenway et al. [25] noted that the policy missed a much larger pool of electricity use associated with the energy used for water provisions at the household level, which is significantly greater than the energy used at the utility scale. For example, end-use at the household level was found to account for $95 \%$ of all water-related energy use in California [26]. Meanwhile, in Australia, research such as Kenway et al. [27] improved the understanding of the energy footprint associated with urban water and wastewater processes. Research that followed has increasingly focused on electricity use at the consumer-level of the water supply chain, where the greatest proportion of energy is used for water provisions [28-30]. This state-of-the-art research indicates only water-energy efficiency measures at the household level would impact the overall energy-intensity in the water and wastewater sectors. However, operational energy management strategies are fundamental for the environmental and economic sustainability of the water and wastewater sectors.

We have not identified any studies that publish high temporal resolution data on water-related energy use in the water and wastewater systems of E\&W. There have been numerous calls in $\mathrm{E} \& \mathrm{~W}$ to conduct integrated nexus analyses in the modelling of water-energy systems $[31,32]$, but this can be challenging to realise in the absence of accessible region-specific empirical data [33]. Additionally, the water sector in $\mathrm{E} \& \mathrm{~W}$ is of international importance in research, particularly due to its relative level of development and experience with privatisation. Therefore, evidence from the E\&W should form an important contribution to the literature seeking to understand the energy influence of urban water and wastewater operations at a global scale, which for the moment does not report much data from the $\mathrm{E} \& \mathrm{~W}$.

With this clear literature gap in mind, we present the first water-related energy use metrics for the E\&W through a novel case-study of the largest water and wastewater utility in the E\&W, Thames Water Utilities Ltd. (TWUL), which is also responsible for serving one of the largest mega-cities in the world, London. To do so, we analysed five years of monthly data on electricity consumption across the TWUL system, which were provided to us by the utility company. The purpose of this work is: (1) to produce the first water- and wastewater-related energy metrics in the context of the United Kingdom; (2) to present a statistical method to separate the trend, seasonal effect and random component from the electricity use time series; and (3) to compare and contrast water and wastewater electricity use in our study against those from other parts of the world. It is important to recognise the system boundaries for analyses of water-related energy [25], and thus we note that this current study considered the the energy use related only to water and wastewater industry operations, and did not deal with electricity for water provisions at the consumer level.

In this manuscript, we firstly present the TWUL system, details of the company, the data that we received from them, and how these data were processed and analysed (Section 2). We then present the the temporal evolution of electricity consumption across the TWUL system by their functional 
category and how usage in the region compares with other parts of the world (Section 3). Finally, we provide concluding remarks on our findings (Section 4).

\section{Materials and Methods}

The main purpose of this study was to derive the first energy-intensity metrics for the water and wastewater systems in E\&W. To do so, we analysed empirical data as follows: (1) time series to understand the trends in energy use and breakdown usage by functions in the supply-chain; (2) each time series was then decomposed using an additive model to understand the long-term trends; and (3) energy-intensity statistics were derived and compared against other regions in the world.

\subsection{Study Area}

This work focuses on the water and wastewater system of TWUL, which is located in the Thames catchment (Figure 1) in South East England. The catchment area covers approximately 16,200 $\mathrm{km}^{2}$ [34]. Within the entire region, TWUL is the largest water utility out of four and the only wastewater utility. The company is also the largest water and wastewater utility company in the United Kingdom and has a customer base of 10 million and 15 million persons in water supply and wastewater, respectively [15]. TWUL is privately owned and has an annual turnover of around $£ 2$ billion. We note that there are three other water supply companies within the region shown in Figure 1 but these utilities are not studied in this work.

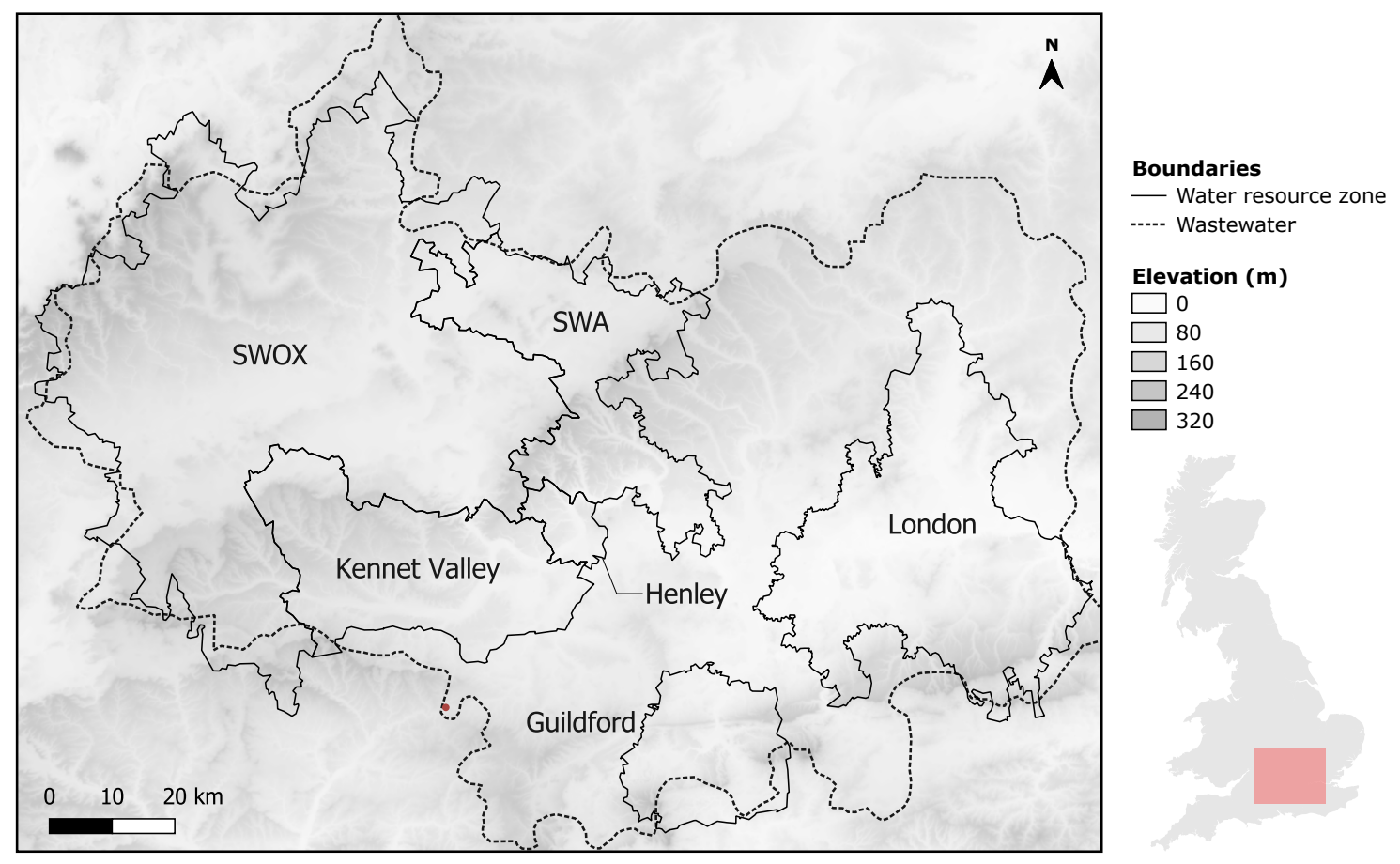

Figure 1. Map of the Thames Water Utilities Ltd. area showing the water supply catchments (black boundaries) and the wastewater resource zone (dotted black line). Elevation is shown in the background.

Water resources are sourced from a combination of groundwater and surface water [34]. Drinking water is supplied to customers through around 32,000 km of water mains, 97 water treatment works, 26 raw water service reservoirs, 308 clean water pumping stations and 235 clean water service reservoirs [35]. As with most of the UK, a combined system conveys both sewage and urban stormwater runoff through the same sewer network. Post-use wastewater and stormwater drainage is captured and transferred through 109,000 km of sewerage mains and 4780 wastewater pumping stations, and is 
eventually treated at one of 351 wastewater treatment works in the area [35]. After employee costs, electricity represents the largest operational expense for TWUL at approximately $£ 130$ million per year, which represents around $14 \%$ of the total operational cost. Of this total sum, around $42 \%$ and $39 \%$ can be apportioned to the water and wastewater systems, respectively [36]. Given the significance of the electricity expenditure, there have been concerted efforts from the utility to better understand opportunities for efficiency gains. During the 2017-2018 business period, TWUL reportedly self-generated a fifth of their total electricity demand, which is equivalent to $293 \mathrm{GWh}$ and $£ 30$ million in operational expenditures [35]. As is the case for many water and wastewater utilities, there are a number of sources of inefficiencies across the ageing system such as old and inefficient pumping stations and treatment plants. However, leakages in the water supply system is widely recognised as the major inefficiency, reported to be around $26 \%$ of the total output from water treatment plants [37]. The utility plans to reduce the overall leakage in the network by $15 \%$ in the period between 2020 and 2025 [35]. Further, the process of replacing aging infrastructure and optimising process operations is continuous. At the demand-side, TWUL plans to install 300,000 smart meters by 2020 (current levels are around 250,000 [35]) to manage overall demand [34].

Figure 1 illustrates the Thames Catchment with the local elevation profile, as well as the major cities within the area. The TWUL water supply area is divided into six Water Resource Zones (WRZs), which represent a standard geographical unit for water resources planning. Descriptive statistics of each WRZ can be found in Table 1. The UK Environment Agency [38] define a WRZ as "an area within which the abstraction and distribution of supply to meet demand is largely self-contained... so that all customers in the WRZ should experience the same risk of supply failure and the same level of service for demand restrictions". As can be observed in Figure 1, the largest WRZ is the area encompassing Swindon and Oxford (SWOX), which is followed by the London WRZ encompassing the Greater London region. Both of these regions are largely reliant on river-based abstractions. The other four zones are Kennet Valley, Henley, SWA (comprising Slough, Wycombe and Aylesbury) and Guildford. These WRZs are relatively smaller in area and are reliant on both groundwater and river abstractions.

Table 1. Summary statistics related to the water supply system for each Water Resource Zone (WRZ) as of 2014. Energy use and intensity were calculated in this study, whereas population and water demand were obtained from Thames Water [39]. The final row shows a sum for the entire Thames Water system with the exception of the $\epsilon$ column, where a mean value is shown.

\begin{tabular}{|c|c|c|c|c|}
\hline Water Resource Zone & Population (p) & Water Demand (ML d ${ }^{-1}$ ) & Energy Use (GWh Year $\left.{ }^{-1}\right)$ & $\epsilon\left(\mathrm{kWh} \mathrm{m}^{-3}\right)$ \\
\hline Guildford & 150,136 & 44.7 & 10.6 & 0.65 \\
\hline Henley & 49,082 & 13.1 & 3.4 & 0.71 \\
\hline Kennet Valley & 389,946 & 98.4 & 32.9 & 0.92 \\
\hline London & $6,946,620$ & 2048.1 & 389.2 & 0.52 \\
\hline SWA & 507,627 & 135.7 & 31.4 & 0.63 \\
\hline SWOX & 999,996 & 261.9 & 44.7 & 0.47 \\
\hline Thames Water & $9,043,407$ & 2602.0 & 512.2 & 0.65 \\
\hline
\end{tabular}

\subsection{Electricity Data}

For this study, we analysed telemetry data that were provided by TWUL between September 2009 and 2016 (60 months). The data are aggregated electricity consumption statistics at monthly time-resolution produced by a proprietary energy auditing system. The primary data (which were not made available for this study) were generated by asset-level electricity meters at half-hourly to daily resolution before being aggregated to the monthly timescales by the energy auditing system. The sample covered 395 sites in total, including: (1) 139 water pumping stations; (2) 112 wastewater pumping stations; (3) 98 wastewater treatment plants; (4) 40 water treatment plants; (5) 1 desalination plant; and (6) 5 other sites including facilities, laboratories and properties. 


\subsection{Time Series Analysis}

Electricity consumption data $\left(\mathrm{kWh} \mathrm{month}^{-1}\right)$ for each asset were aggregated by functional categories and converted into time series following a similar approach to previous studies $[40,41]$. By functional categories, we refer to following specific operations in the supply-chain: (1) wastewater treatment; (2) wastewater networks; (3) water treatment; (4) water networks; (5) desalination; and (6) other auxiliary functions. Time series of electricity use in water systems have previously been observed to exhibit strong seasonality driven by seasonal patterns in demand [40]. The electricity consumption data also show an overall trend in accordance with, for instance, growth in water demands. Finally, abnormal fluctuations from the mean of the time series might also be observed caused by upsurges in demand during events such as major holidays and sporting events, amongst other factors including weather events. However, these cannot be captured within a long-term seasonal or trend component, and so can be considered as a statistically random component within the time series. Therefore, to understand the influence of such factors on the overall electricity consumption, we use the Seasonal and Trend decomposition method using Loess (STL), which was developed by Cleveland et al. [42] and decomposes the time series $f$ into three components such that:

$$
f_{t}=\alpha_{t}+\beta_{t}+\gamma_{t}
$$

where $\alpha$ represents the long-term trend in the time series, providing an understanding of the rate of change in the series. The $\beta$ component captures the seasonal effects in the data, which in the case of water and wastewater flows could be linked to seasonal changes in demand and climate effects. Finally, $\gamma$ represents a stochastic irregular (random) component that would represent one-off events that can result in unusual fluctuations in the time series. We used the STL procedure as it is a versatile and robust additive time series decomposition method [43] and it has been successfully demonstrated in a significant number of different applications, which includes analysis of electricity consumption data [44]. A sequence of smoothing operations are applied using locally-weighted polynomial regressions. Whilst STL can handle changes in seasonality in time, we assumed that the seasonal phase in each of our time series was constant given the relatively short timescale of the data. The STL technique can handle multiple types of seasonality, allows the user to define the smoothness of the trend-cycle and is robust to outliers in its estimation of the trend and seasonal cycles [43]. A more detailed description of this method, as well as other variants of this technique, can be found in the work by Hyndman and Athanasopoulos [43]. The trend in electricity consumption was then evaluated by applying a least-squares regression model on the $\alpha$ component and the slope (first-order derivative) was computed, which allowed us to understand whether consumption was changing in time. All rates of change reported in this work were obtained from the gradient estimation from the least-squares regression model, where the uncertainty is taken as the standard-error in the model.

\subsection{Calculating Energy-Intensity}

Energy-intensity $\epsilon$, measured as the unit energy use per unit of water demand or wastewater treated $\left(\mathrm{kWh} \mathrm{ML}^{-1}\right)$, is a common metric used globally for assessing the energy intensiveness of a water system $[3,27,45]$. Previous works have tended to present $\epsilon$ metrics per functional category in a water or wastewater system $[27,40]$. However, since we did not have time series data on water flows through each of the 395 sites analysed in this work, we could not compute energy-intensity metrics for each site or by functional units. Therefore, $\epsilon$ metrics in this work were computed for each of the six water resource zones in the Thames catchment, which are presented in Figure 1. For each water resource zones, $\epsilon$ was calculated following Lam et al. [22] as:

$$
\epsilon_{z}=\frac{\varphi_{z}}{\zeta_{z}}
$$


where $\varphi$ is the electricity consumption per capita $\left(\mathrm{kWh} \mathrm{p}^{-1}\right), \zeta$ is the water use per capita $\left(\mathrm{m}^{3} \mathrm{p}^{-1}\right)$ and $z$ denotes the specific water resource zone. The per capita use of water and energy are calculated respectively as:

$$
\begin{gathered}
\varphi_{z}=\frac{\sum_{t=1}^{n} f_{t, z}}{P_{z}} \\
\zeta_{z}=\frac{\sum_{t=1}^{n} w_{t, z}}{P_{z}}
\end{gathered}
$$

where $f$ is a time series of electricity consumption $(\mathrm{kWh})$ of a specific water resource zone $z, \omega$ represents the total water used across the water resource zone within the same time period $\left(\mathrm{m}^{3}\right)$ and $P$ is the total population (number of persons). Values for the total water used $\omega$ and population $P$ in each water resource zone were obtained from Thames Water [39] and originally estimated from internal TWUL modelling based on metering data. The total water use equivalent is the total quantity of water produced, which is the sum of residential and non-household demand, as well as system leakages. These data are summarised in Table 1. The derived metrics for energy-intensity were then compared locally to understand regional spatial variations. We note that this current investigation did not consider wastewater energy-intensity as the required data were not available.

\section{Results and Discussion}

\subsection{Temporal Evolution of Electricity Use}

Figure 2 shows the time series of total electricity consumption $f_{t}$ across the TWUL system between September 2009 and 2014 per functional category. Across the 60-month time-period, the total electricity use in the system was $4426 \mathrm{GWh}$, which is equivalent to $870 \mathrm{GWh}$ year $^{-1}$ of consumption. This electrical input facilitated the delivery and treatment of $2.5 \times 10^{6} \mathrm{~m}^{3}$ day $^{-1}$ of water and $3.4 \times 10^{6} \mathrm{~m}^{3}$ day $^{-1}$ of wastewater, respectively. In descending order, the main contributors to the total energy consumption over the study period were observed to be water networks (33\%), wastewater treatment $(32 \%)$, water treatment $(24 \%)$, wastewater networks $(6 \%)$ and desalination $(2 \%)$. The remainder of consumption $(1 \%)$ was in other operations such as laboratories, properties and maintenance work, and is not discussed any further in this work due to the negligible overall contribution of this category. Although the total number of assets in the TWUL system per functional category exceeds the assets for which we have data for (see Section 2.1), we note that those sites that are not considered in this work are relatively small facilities, and their energy consumption is not considered material in the context of this study.

In observing the temporal evolution of the total electricity consumption, a consistent increasing trend in electricity usage is evident across the system during the study period. Between the first and last time-period, monthly electricity consumption grew from 56 to $86 \mathrm{GWh}$. In Figure 3, we can see the observed time series $f$, trend $\alpha$, seasonal phase $\beta$ and random component $\gamma$, which are shown in Rows 1-4 of the panel plot, respectively. To ensure the model has adequately captured each phase, we further analysed the $\gamma$-phase and observed a random distribution with no autocorrelation. We observe the mean contribution from seasonality $\beta$ and random effects $\gamma$ as minor components of the time series $f$ at $0.10 \%$ and $0.12 \%$, respectively. Given the relatively short timescale of our case-study, we assumed the seasonal cycle remained constant in our analysis but we note this assumption could lead to erroneous representation of the seasonal phase. Future studies that employ this method should calibrate the model to better capture the seasonal cycle, particularly if the influence of climate change on energy-use in water and wastewater operations is an important aspect of the study. The random component of the model shows a generally consistent pattern during 2010-2013, after which more variability is exhibited, which suggests that an exceptional event might have occurred that could have led to an increase from usual levels of electricity use. Once the time series has been adjusted for seasonality and random effects, we observe a strong growth in the long-term trend component $\alpha$ during the study 
period, with an equivalent rate of change of $67 \pm 0.3 \mathrm{GWh}_{\text {year }}{ }^{-1}\left(10.8 \pm 0.4 \%\right.$ year $\left.^{-1}\right)$. The rate was estimated by fitting a linear regression model to $\alpha$ and computing the slope of the model, where the error is assumed as the standard error in the model estimation. More recent statistics from TWUL public reports suggest this growth continued: total electricity consumption across the network was reported to be $941 \mathrm{GWh}$ in 2017-2018 [46]. This later reported consumption exceeds the expected value if we were to extrapolate using the rate of change observed over the time slice of the data in this study. This might be attributed to a number of factors including: (1) a significant increase of pumping into reservoirs to meet a sudden increase in summer demand; (2) an unexpected cold wave and increased pipe bursts in February 2018; and (3) the exceptionally hot and dry summer of 2018 [46].

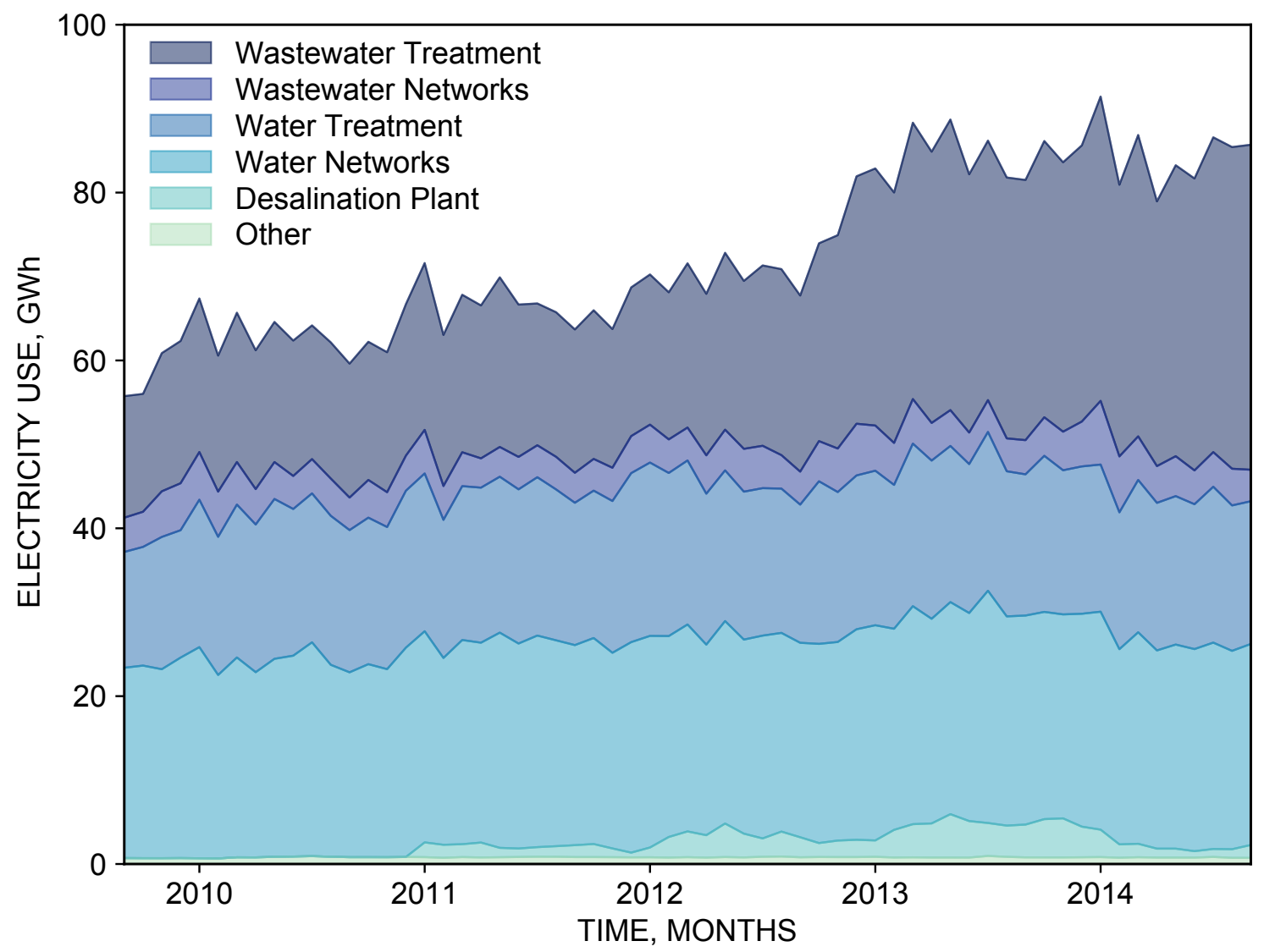

Figure 2. Observed electricity consumption (GWh) between 2009 and 2014 across the Thames Water Utilities Ltd. system. Time series are categorised by different operations within the utilities' network.

Figure 4 shows the derived trend components from the time series decomposition of each functional category, which have been plotted as the relative change (\%) using the first value in the time series as the base value. Here, we can clearly observe a strong growth in the electricity requirements for wastewater treatment. Between 2010 and 2012, electricity use in wastewater treatment works grew by approximately $10 \%$, after which it increased dramatically by $\sim 110 \%$ to the end of the time series. After conferring with operations managers from TWUL, we learned that this sudden growth can be attributed to major modifications in five of the utility's largest wastewater treatment works, where the following unit operations were added: (1) 12 aeration plants; (2) 2 picket fence thickeners; (3) 2 activated sludge thickeners; (4) 24 final settlement tanks; (5) 5 primary settlement tanks; and (6) 2 inlet pumps. Furthermore, exceptional levels of flooding within this period resulted in larger than normal volumes of stormwater entering the sewer system, which led to additional levels of associated pumping. Across the other functional categories (i.e., water networks, water treatment and wastewater networks), we do not observe any statistical significance trend in the relative energy 
consumption, and thus we conclude the increases in electricity consumption observed across the TWUL system are mainly attributed to the modifications in wastewater treatment operations, as well as increased volume of wastewater pumping induced by flooding.

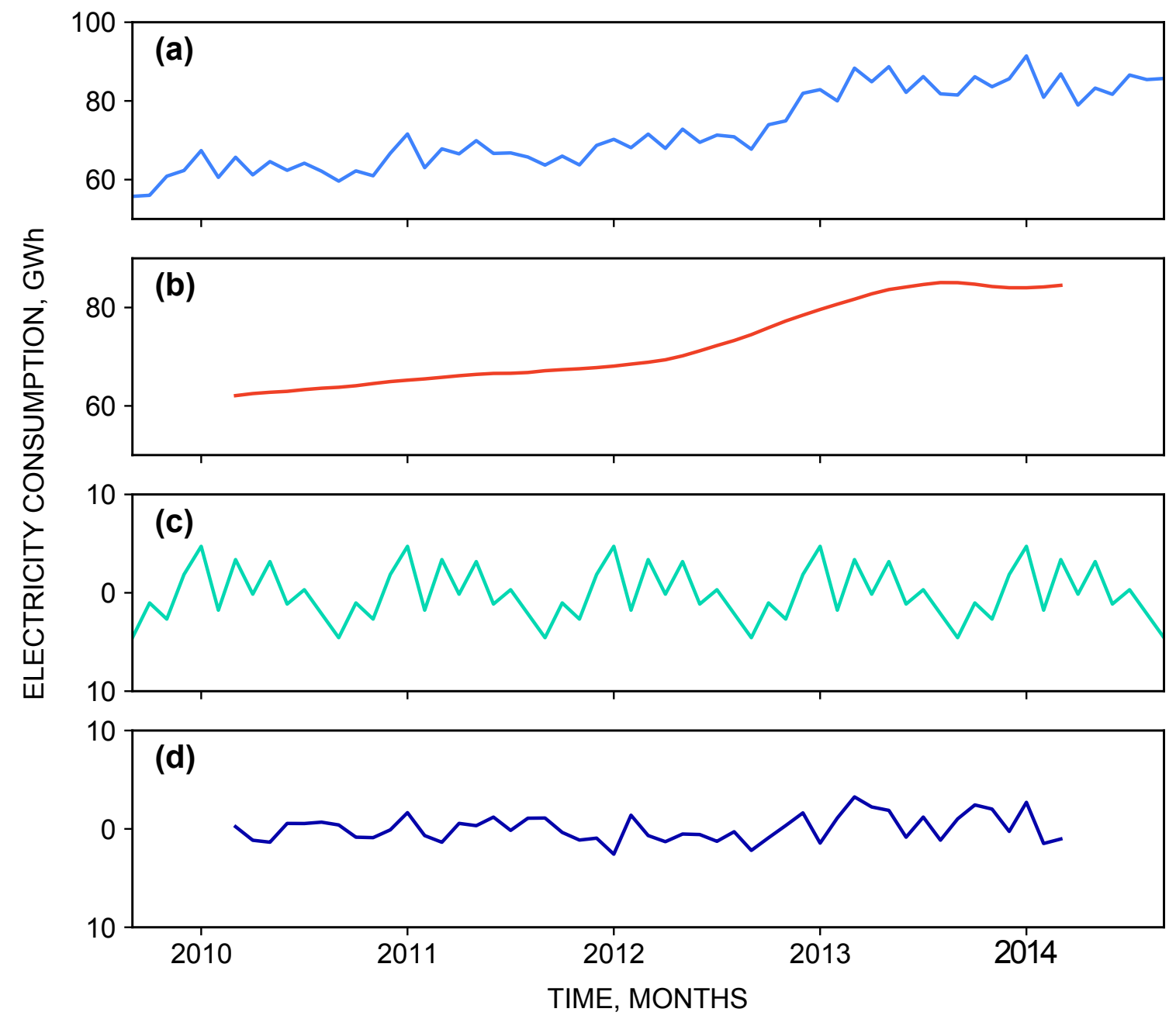

Figure 3. Decomposition of total electricity consumption (GWh) in the Thames Water Utilities Ltd. system:

(a) the observed time series $f ;(\mathbf{b})$ the trend $\alpha ;(\mathbf{c})$ the seasonal phase $\beta$; and (d) the random component $\gamma$.

Some of the increasing trends in electricity use can also be attributed to the commissioning of the Beckton Desalination Plant, which is first desalination facility in the United Kingdom and became fully operational in late 2010 [47]. The plant was designed to treat brackish water, which has a lower saline content than seawater, and hence requires less treatment. Beckton is only used at times of drought. Whilst desalination is typically synonymous with high electricity consumption-e.g., Sydney's desalination plant consumed 257.7 GWh of electricity in 2010 [48] - the single desalination plant in the Thames catchment is not used frequently. The Beckton Desalination Plant has on average only processed around $23 \%$ of its capacity $\left(150 \mathrm{ML}\right.$ day $\left.^{-1}\right)$ since it came online, and yet a notable electricity footprint can be observed associated with its use in Figure 2 between 2011 and 2014, contributing around $2 \%$ to the total electricity use. The energy-intensity of the plant was estimated as $2.26 \mathrm{kWh} \mathrm{m}^{-3}$, which is within the upper-range of $1.0-2.5 \mathrm{kWh} \mathrm{m}^{-3}$ reported for brackish water $\mathrm{RO}$ in previous studies $[5,8]$. As water scarcity pressures enhance in the future, the use of the Beckton Desalination Plant could potentially increase if other water resource options with lower energy needs are not developed, which would translate into a higher water-related electricity footprint. Outside of the Thames catchment, there are suggestions that additional desalination plants might be required 
in the UK $[49,50]$, which would enhance the electricity footprint of water supply across the country, although the feasibility of desalination as a solution elsewhere in England and Wales remains uncertain.

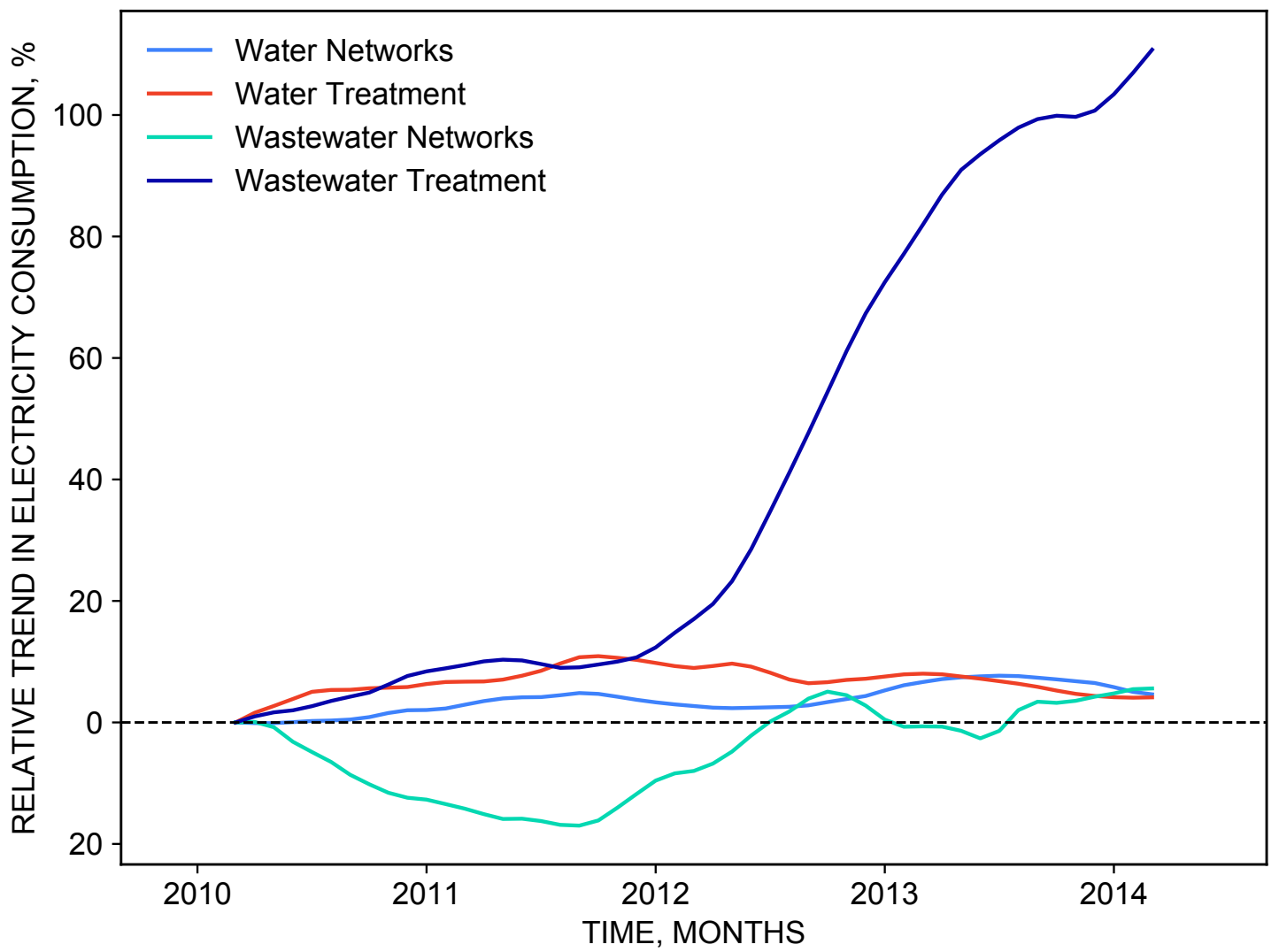

Figure 4. Derived trend components $(\alpha)$ for each functional category: water networks, water treatment, wastewater networks and wastewater treatment. Shown as relative change (\%) using the first term in the time series as the base value.

\subsection{Electricity Use by Function}

The three most electricity-consumptive functions in the TWUL system were observed to be water networks (33\%), wastewater treatment (32\%) and water treatment $(24 \%)$. In water supply networks, electricity consumption is primarily a function of water demands, as well as network conditions with respect to hydraulic properties of the pipe (i.e., velocity, pressure head, frictional losses, etc.), asset age and topography. Post-treatment leakages within the TWUL system are currently reported to be $26 \%$ of the total demand and the company is targeting to reduce this number by $15 \%$ during the period 2020-2025 [35]. This would theoretically result in decreased electricity consumption within the water distribution network as sources of water losses are removed and older assets are replaced [51]. In addition, reducing losses in the water network would also lower the throughput needed in water treatment plants, and so reduce the associated electricity use. However, any benefits that are potentially realised here would be offset by population growth.

Analysis from TWUL predicts an increase in overall water demands at a rate of $0.25-0.75 \%$ year $^{-1}$, which is associated with population growth scenarios [39]. However, plans to implement smart meters and relatively more water-efficient technologies such as modern dishwashers, washing machines and low volume toilet cisterns will help to temporarily offset the increases in water demands, by reducing per capita consumption [39].

The most common method for sewage collection across England and Wales is through combined sewage systems, in which sewage from domestic, industrial and commercial sources is combined with surface runoff and distributed to local wastewater treatment plants. Combined sewer overflows 
(CSOs), which is when the total inflows into a combined sewer exceed its capacity causing the discharge of untreated wastewater into local water bodies, have been long recognised as an environmental and public health risk in the Thames catchment, and indeed in other catchments across England and Wales [52,53]. As such, TWUL have targets to reduce overflow events in certain areas. One such project to deal with this issue is the Thames Tideway Tunnel-a 25-km long and 7.2-m diameter sewer that is being bored under the River Thames expected to be completed by 2024 at an estimated cost of $£ 4.9 \mathrm{bn}$ [54]. The sewer has been designed to reduce the frequency of overflow events from 50-60 to 3-4 per year, which will facilitate the UK Government becoming compliant with the EU Urban Wastewater Treatment directive [55]. This project will immediately yield significant public health, environmental and aesthetic benefits $[53,55,56]$ as overflows events are reduced and more wastewater is directed to local treatment plants. With more water being pumped out of the tunnel and increased inflows into wastewater treatment plants, the electricity use in the wastewater supply chain will increase as a result. It is important to track the energy influence such major implementations as this would form a useful planning guide for other similar projects globally.

\subsection{System Energy-Intensity}

Figure 5 shows water-related energy use $\left(\mathrm{kWh} \mathrm{p}^{-1}\right.$ year $\left.{ }^{-1}\right)$ against water use $\left(\mathrm{L} \mathrm{p}^{-1} \mathrm{~d}^{-1}\right)$ in the TWUL system (in colour) compared against other regions in the world (grey) for the review period. We note that this chart shows data for water supply only and energy for water use at the household level is not included. Dashed lines in the plot, which indicate linear functions of energy-intensity between 0.5 and $2.0 \mathrm{kWh} \mathrm{m}^{-3}$ have been shown for reference. We observe that the per capita water demands in the Thames catchment are within the average range of the other cities reported. Whilst the observed energy-intensities are generally above the average of all the cities plotted $\left(0.6 \mathrm{kWh} \mathrm{m}^{-3}\right)$, both SWOX and London, where the greatest populations are served, are below this average value. Further, altthough we recognise the potential for differences in drinking water quality standards globally and hence treatment requirements, the energy-intensity values derived are higher than those calculated for similarly developed cites, such as Melbourne, Berlin, Sydney and San Francisco. It should be recognised, however, that the regions studied in this work are water resource zones, and so the spatial extents might vary in comparison to the other regions in the plot, which consider only the city-scale or are an aggregate of all encompassing water supply zones.

Factors that influence the energy-intensity of water-related energy use are known to include climate, topography, water use patterns and operational efficiency [22,41]. In addition, the initial raw water quality as well as the required water quality parameters of the final product also influence the electricity requirements of the system. The energy-intensity values derived for the TWUL system can likely be explained by two factors: (1) the volume of pumping in the system; and (2) low system efficiency attributed to relatively high leakage rates. The TWUL system requires relatively high amounts of pumping to convey water between process operations, which is likely due to little topographical variation within water resource zones. Secondly, the energy intensiveness of the TWUL system could also be explained by system leakages, which are known to be relatively high across the network [57]. Sections of the supply network are among the oldest in the world and date back to the Victorian era. Further, recent network maintenance reviews revealed the annual asset replacement rates in the network are small-scale in comparison to other parts of the world [58]. Age of a network has been known to correlate with higher leakages in a water distribution network [59], which could explain the relatively high levels of leakages in the TWUL system. Leaks in the system are well-known to increase the energy consumption in a water system in two ways: (1) by increasing the need to abstract, treat and output larger volumes of water into the distribution network; and (2) through greater dynamic losses that result from restoring equivalent service [51]. The utility has targets to reduce leakage rates by fixing or replacing assets within the network, which would yield savings in electricity consumption in the short-term. 


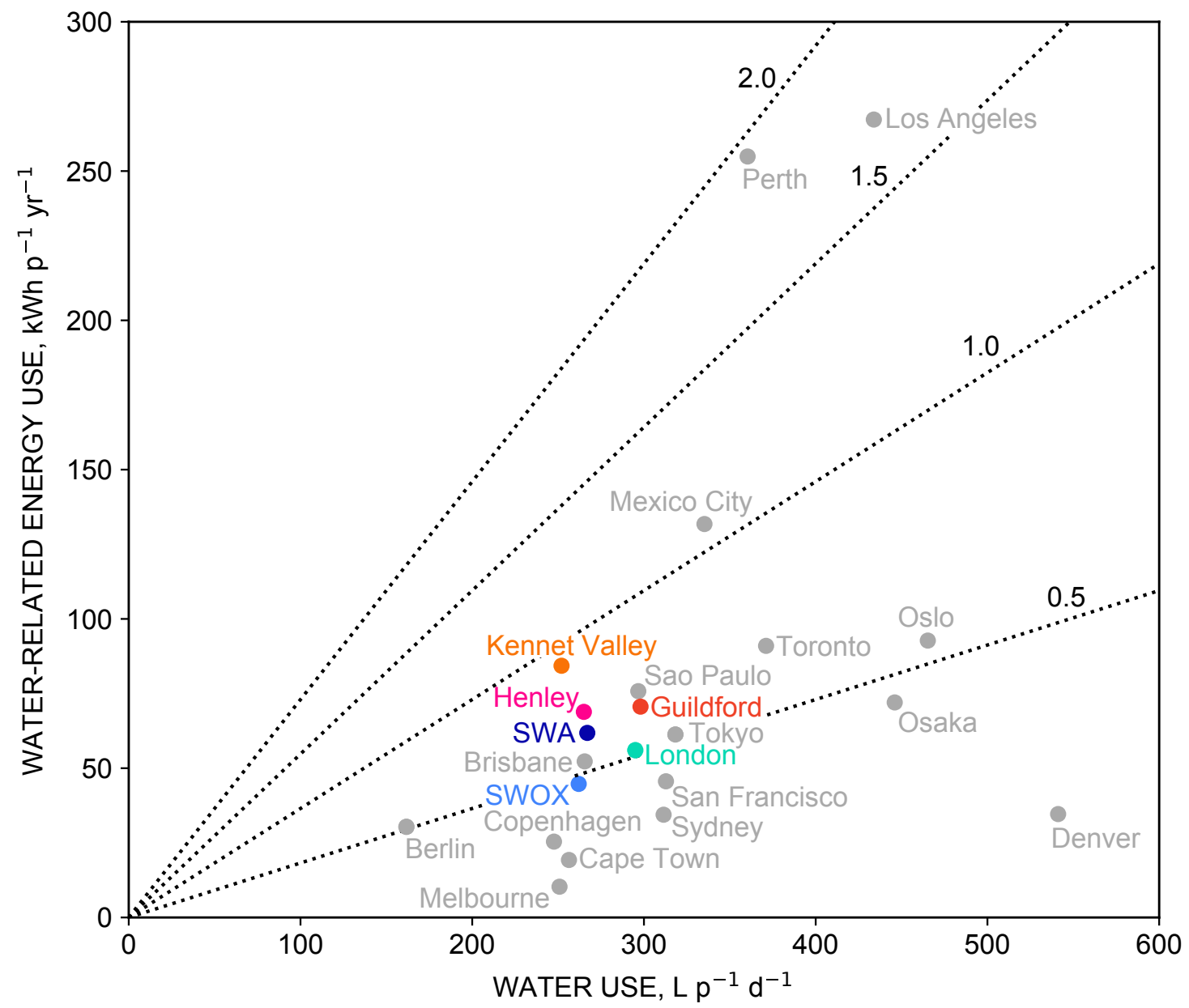

Figure 5. Water-related energy use $\left(\mathrm{kWh} \mathrm{p}^{-1}\right.$ year $\left.{ }^{-1}\right)$ against water use $\left(\mathrm{L} \mathrm{p}^{-1} \mathrm{day}^{-1}\right)$ in the Thames Water Utilities Ltd. system in 2012 compared against other regions in the world (grey). The dotted lines are plotted for reference and indicate $0.5-2.0 \mathrm{kWh} \mathrm{m}^{-3}$ energy intensities. Data for other regions were obtained from Lam et al. [41].

Identifying and reducing leakage across the water distribution network has benefits towards an energy efficient system. However, this can come at a significant cost. Figure 6 shows the relationship between capital cost investments and leakage reductions, which is based on an analysis by TWUL [60]. The curve assumes an exponential relationship between leakage reduction and capital cost, in that significant reductions could be realised cost-effectively in the first instance but the economic case decreases after a turning point. The dashed line in Figure 6 represents the targeted leakage reduction by the utility up to 2020: $85 \mathrm{ML} \mathrm{d}^{-1}$ with an expected cost of around $£ 340$ million. For relative context, this volume of water could meet $96 \%$ of the daily demands of the Guildford, Henley and Kennet Valley water resource zones $(589,164$ people) [39]. There are a number of benefits of reducing leakages that regulators and utilities in the UK have recognised, and whilst energy savings are also acknowledged they have not yet been quantified in terms of potential reductions in operational expenditure. That is, what would be the unit cost saving for each unit of water leakage prevented? Using the metrics for energy-intensity $\left(\mathrm{kWh} \mathrm{m}^{-3}\right)$ derived in this work, we have expressed this relationship in terms of the energy cost savings that could be realised for every unit reduction in leakage (calculation shown in Appendix A). Should the utility reach its target, this could result in a theoretical reduction of $85 \mathrm{ML} \mathrm{d}^{-1}$, which is approximately equivalent to operational expenditures due to electricity consumption of $\sim £ 2.1$ million year $^{-1}$. This number accounts for around $2 \%$ of the total operational expenditure associated with importing grid electricity. However, there is a caveat to this theoretical value as it is derived in the absence of other external pressures such as population growth and demand changes 
in time. Discourse on the motivations for leakage reductions primarily focus on the environmental benefits of reduced water withdrawals from rivers, as well as the improvement in political and public perception, and less often focuses on the energy-related co-benefits.

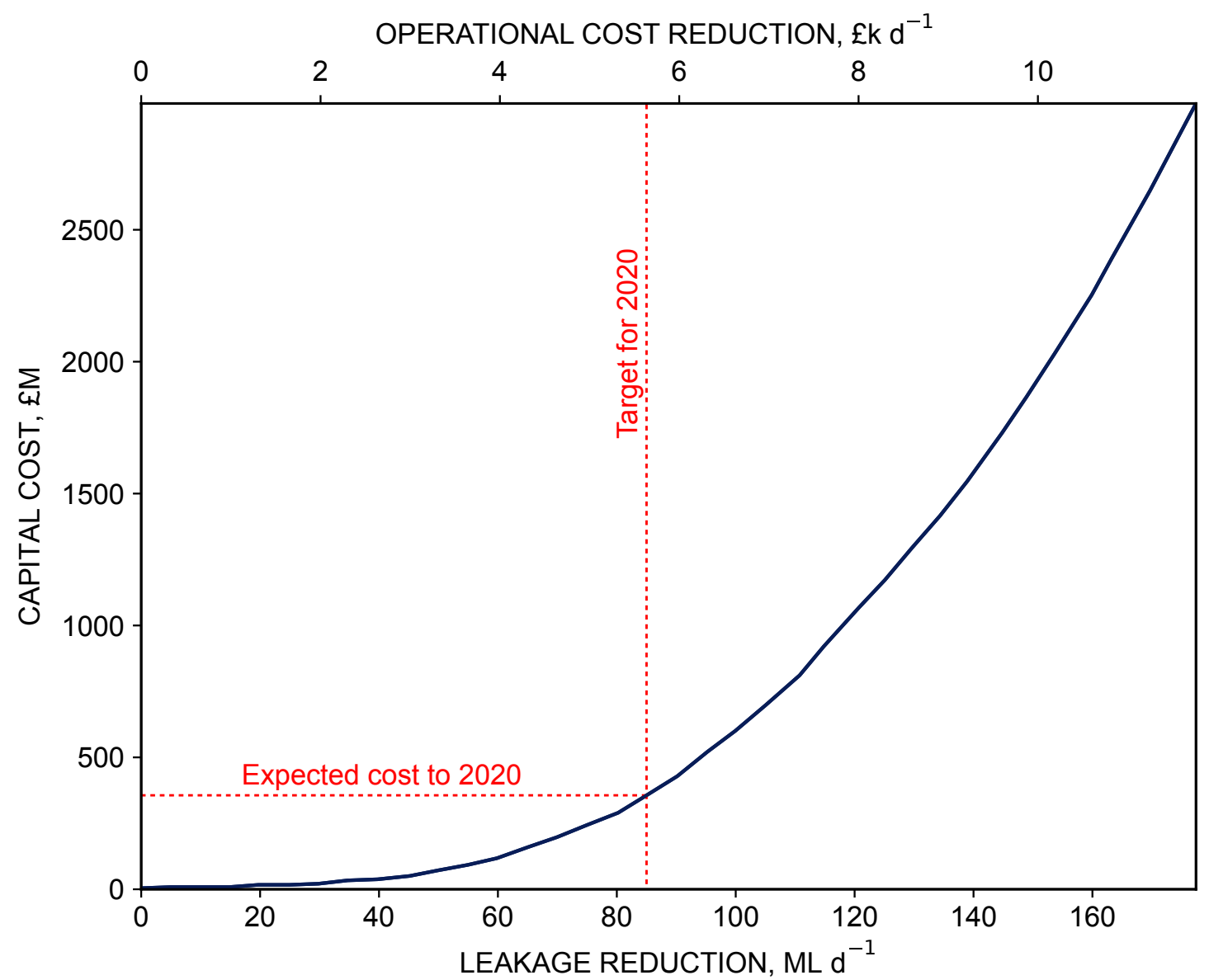

Figure 6. Curve expressing the relationship among capital cost ( $£$ millions), leakage reductions $\left(\mathrm{ML} \mathrm{day}^{-1}\right)$ and reductions in operational expenditures due to electricity consumption $\left(£ 1000\right.$ s day $\left.^{-1}\right)$ for the Thames Water Utilities Ltd. system. The dashed red lines show the company's leakage reduction targets to 2020 [60].

\section{Conclusions}

Electricity consumption in the TWUL network increased consistently during the period 2009-2014, which was mainly driven by expansions in wastewater treatment works to achieve higher effluent water quality standards and periods of heavy rainfall, which led to more stormwater pumping and treatment, as well as the use of a new desalination plant. As the utility continues to invest in more water supply technologies to meet increasing demands, as well as upgrade its sewer and wastewater treatment capacities, we can reasonably expect this growth in electricity consumption to continue. However, some of this growth could be managed should the planned improvements to water infrastructure efficiency (e.g., leakage reductions) be realised. However, the temporary nature of these benefits should be recognised as external pressures such as stricter water quality standards and population growth would offset the potential benefits. With regards to energy use in wastewater operations, regulatory changes require utilities to reduce overflow events in combined sewage networks. Whilst this will reduce the number of discharges of untreated wastewater into local water bodies, it will result in increased pumping of wastewater and larger volumes for wastewater plants to handle, which might increase the associated electricity usage. However, implementation of source control measures for stormwater runoff in urban areas could potentially mitigate the energy consumption impacts. This 
highlights the fact that increasing stringency in mandatory effluent standard regulations will generally be associated with higher energy requirements.

When analysing the derived energy-intensity metrics for each water resource zone in the water utility's system, we discovered that energy-efficiency of water supply, in terms of the electricity usage per unit of water delivered, is within the average range when compared against similarly developed cities across the world. Given that TWUL has plans to improve the efficiency of their system through management schemes such as leakage reduction, the energy-intensity of the network and the operational expenditures associated with electricity could decrease in the short-term as a result, although the benefits would erode in time as a result external factors such as population growth. This study did not deal with the energy used for water provisions at the household level. However, it has been estimated that customers of TWUL use seven times more electricity for water-related services as compared to the utility's electricity use for their operations, which is also the case for many other regions across the world. It is therefore also important to target opportunities for water-related efficiency improvements at the consumer level. State-of-the-art frameworks used to understand and improve water-related energy use should be clearly separated to define energy use in industry from that at the household level.

Temporal studies of the energy influence of water-related operations are rare. Through this study, we have have seen that such studies can be useful in better understanding the energy-related characteristics of a water and wastewater systems. This is particularly important in relation to understanding long-term electricity consumption trends, which can reveal insights on the energy impacts of infrastructure and effectiveness of policy development, and to understand the exogenous seasonal and random influence from the local environment. The information that can be gleaned from such analyses are an important basis for effective energy management programmes in water and wastewater operations.

Author Contributions: A.M. prepared the manuscript, processed and analysed the data and generated the figures presented in this work. I.C. processed the data used in this work and provided input into the manuscript preparation. C.Z. assisted in the data analysis and manuscript preparation. T.R. helped prepare the visualisations and reviewed the manuscript. This work was conducted under the supervision of K.C., R.B.-A. and J.W.H. All authors have read and agreed to the published version of the manuscript.

Funding: A.M. is a candidate on the Environmental Research Doctoral Training Programme at the University of Oxford and is funded by the Natural Environment Research Council (NERC reference: NE/L002612/1) and EDF Energy. I.C. was funded by the La Caixa Foundation and Thames Water Utilities Ltd. A.M., C.Z., J.W.H. and T.R. acknowledge the contribution of the Infrastructure Transitions Research Consortium (ITRC), which is funded by the UK Engineering and Physical Sciences Research Council (EPSRC) under two programme grants $\mathrm{EP} / \mathrm{I01344X/1}$ and EP/N017064/1. This work received no additional external funding.

Acknowledgments: The authors are grateful to Thames Water Utilities Ltd. for their cooperation and support in this study. This manuscript was improved due to useful comments from two anonymous reviewers.

Conflicts of Interest: The authors declare no conflict of interest that could have influenced the representation and interpretation of the reported research results. The views and opinions expressed in this paper are those of the authors and are the product of on-going research. They do not represent the position or opinions of either the University of Oxford or Thames Water Utilities Ltd.

\section{Appendix A. Cost-Benefit Analysis}

In this section, we discuss the methodology used in the calculations for Figure 6. Data on the capital cost required per megalitre reduction in leakages were produced by TWUL [60]. The benefit in operational expenditure $b$ per unit reduction in leakage was calculated as:

$$
b=\mathcal{L} \cdot \bar{\epsilon} \cdot c
$$

where $\mathcal{L}$ is the leakage reduction $\left(\mathrm{m}^{3} \mathrm{~d}^{-1}\right), \bar{\epsilon}$ is the mean energy-intensity across the Thames network $\left(\mathrm{kWh} \mathrm{m}^{-3}\right)$ and $c$ is the cost of electricity $\left(£ \mathrm{kWh}^{-1}\right)$ for TWUL. The $\bar{\epsilon}$ value was calculated in our analysis as $0.65 \mathrm{kWh} \mathrm{m}^{-3}$. The value of $c$ could be calculated based on reports from TWUL, which 
state that 160.6 GWh of electricity consumption is equivalent to $£ 30$ million in operational expenditures to the utility [35].

\section{References}

1. Water UK. Public Interest Commitment; Technical Report; Water UK: London, UK, 2019.

2. Perrone, D.; Murphy, J.; Hornberger, G.M. Gaining perspective on the water-energy nexus at the community scale. Environ. Sci. Technol. 2011, 45, 4228-4234. [CrossRef] [PubMed]

3. Rothausen, S.G.; Conway, D. Greenhouse-gas emissions from energy use in the water sector. Nat. Clim. Chang. 2011, 1, 210. [CrossRef]

4. Mo, W.; Zhang, Q.; Mihelcic, J.R.; Hokanson, D.R. Embodied energy comparison of surface water and groundwater supply options. Water Res. 2011, 45, 5577-5586. [CrossRef]

5. Plappally, A.; Leinhard, J. Energy requirements for water production, treatment, end use, reclamation, and disposal. Renew. Sustain. Energy Rev. 2012, 16, 4818-4848. [CrossRef]

6. Racoviceanu, A.I.; Karney, B.W.; Kennedy, C.A.; Colombo, A.F. Life-cycle energy use and greenhouse gas emissions inventory for water treatment systems. J. Infrastruct. Syst. 2007, 13, 261-270. [CrossRef]

7. Elimelech, M.; Phillip, W.A. The future of seawater desalination: Energy, technology, and the environment. Science 2011, 333, 712-717. [CrossRef] [PubMed]

8. Stokes, J.; Horvath, A. Life cycle energy assessment of alternative water supply systems. Int. J. Life Cycle Assess. 2006, 11, 335-343. [CrossRef]

9. Siddiqi, A.; Anadon, L.D. The water-energy nexus in Middle East and North Africa. Energy Policy 2011, 39, 4529-4540. [CrossRef]

10. Gallego, A.; Hospido, A.; Moreira, M.T.; Feijoo, G. Environmental performance of wastewater treatment plants for small populations. Resour. Conserv. Recycl. 2008, 52, 931-940. [CrossRef]

11. Siddiqi, A.; de Weck, O.L. Quantifying End-Use Energy Intensity of the Urban Water Cycle. J. Infrastruct. Syst. 2013, 19, 474-485. [CrossRef]

12. Nair, S.; George, B.; Malano, H.M.; Arora, M.; Nawarathna, B. Water-energy-greenhouse gas nexus of urban water systems: Review of concepts, state-of-art and methods. Resour. Conserv. Recycl. 2014, 89, 1-10. [CrossRef]

13. Veolia. $\mathrm{H}_{2} \mathrm{O} 27$ : Future-Proofing UK Water; Technical Report; Veolia: London, UK, 2017.

14. Watson, J.; Rai, N. Governance Interdependencies between the Water \& Electricity Sectors; Technical Report; Infrastructure Transitions Research Consortium: Oxford, UK, 2013.

15. Thames Water. Annual Report and Annual Performance Report 2018-2019. Available online: https://corporate.thameswater.co.uk/-/media/Site-Content/Thames-Water/Corporate/AboutUs/ Investors / Annual-report/2019/2018-19-Annual-Report-and-Annual-Performance-Report.pdf (accessed on 3 April 2019).

16. United Utilities. Annual Report and Financial Statements for the Year Ended 31 March 2019. Available online: http:/ / unitedutilities.annualreport2019.com/site-essentials/downloads/annual-report-2019 (accessed on 19 August 2019).

17. Ofwat. Water 2020: Regulatory Framework for Wholesale Markets and the 2019 Price Review; Technical Report; Ofwat: Birmingham, UK, 2015.

18. Stokes, J.R.; Horvath, A.; Sturm, R. Water loss control using pressure management: Life-cycle energy and air emission effects. Environ. Sci. Technol. 2013, 47, 10771-10780. [CrossRef] [PubMed]

19. Stokes, J.R.; Hendrickson, T.P.; Horvath, A. Save water to save carbon and money: Developing abatement costs for expanded greenhouse gas reduction portfolios. Environ. Sci. Technol. 2014, 48, 13583-13591. [CrossRef] [PubMed]

20. Spang, E.S.; Holguin, A.J.; Loge, F.J. The estimated impact of California's urban water conservation mandate on electricity consumption and greenhouse gas emissions. Environ. Res. Lett. 2018, 13, 014016. [CrossRef]

21. Kenway, S.; Binks, A.; Lane, J.; Lant, P.; Lam, K.; Simms, A. A systemic framework and analysis of urban water energy. Environ. Model. Softw. 2015, 73, 272-285. [CrossRef]

22. Lam, K.L.; Kenway, S.J.; Lant, P.A. City-scale analysis of water-related energy identifies more cost-effective solutions. Water Res. 2017, 109, 287-298. [CrossRef] 
23. Renouf, M.A.; Kenway, S.J.; Lam, K.L.; Weber, T.; Roux, E.; Serrao-Neumann, S.; Choy, D.L.; Morgan, E.A. Understanding urban water performance at the city-region scale using an urban water metabolism evaluation framework. Water Res. 2018, 137, 395-406. [CrossRef]

24. Klein, G.; Krebs, M.; Hall, V.; O’Brien, T.; Blevins, B. California's Water-Energy Relationship; Technical Report; California Energy Commission: Sacramento, CA, USA, 2005.

25. Kenway, S.J.; Lam, K.L.; Stokes-Draut, J.; Sanders, K.T.; Binks, A.N.; Bors, J.; Head, B.; Olsson, G.; McMahon, J.E. Defining water-related energy for global comparison, clearer communication, and sharper policy. J. Clean. Prod. 2019, 236, 117502. [CrossRef]

26. Escriva-Bou, A.; Lund, J.; Pulido-Velazquez, M. Saving energy from urban water demand management. Water Resour. Res. 2018, 54, 4265-4276. [CrossRef]

27. Kenway, S.; Priestley, A.; Cook, S.; Seo, S.; Inman, M.; Gregory, A.; Hall, M. Energy Use in the Provision and Consumption of Urban Water in Australia and New Zealand; WSAA: Sydney, Australia, 2008.

28. Vieira, A.S.; Beal, C.D.; Stewart, R.A. Residential water heaters in Brisbane, Australia: Thinking beyond technology selection to enhance energy efficiency and level of service. Energy Build. 2014, 82, 222-236. [CrossRef]

29. Kenway, S.J.; Binks, A.; Scheidegger, R.; Bader, H.P.; Pamminger, F.; Lant, P.; Taimre, T. Household analysis identifies water-related energy efficiency opportunities. Energy Build. 2016, 131, 21-34. [CrossRef]

30. Binks, A.N.; Kenway, S.J.; Lant, P.A. The effect of water demand management in showers on household energy use. J. Clean. Prod. 2017, 157, 177-189. [CrossRef]

31. POST. The Water-Energy-Food Nexus; Technical Report; UK Parliamentary Office of Science and Technology (POST): London, UK, 2016.

32. Konadu, D.; Fenner, R.; Richards, K.; Allwood, J. UK Water-Energy Nexus under Climate Change; Technical Report; University of Cambridge: Cambridge, UK, 2017.

33. Khan, Z.; Linares, P.; García-González, J. Integrating water and energy models for policy driven applications. A review of contemporary work and recommendations for future developments. Renew. Sustain. Energy Rev. 2017, 67, 1123-1138. [CrossRef]

34. Thames Water. Our Revised Draft Water Resources Management Plan 2019. Available online: https:// www.thameswater.co.uk/-/media/Site-Content/Your-water-future-2018/WRMP-Glossy.pdf (accessed on 3 April 2019).

35. Thames Water. Facts and Figures. Available online: https://corporate.thameswater.co.uk/Media/Factsand-figures (accessed on 3 April 2019).

36. Thames Water. Cost Assessment Tables 2017/18. Available online: https://corporate.thameswater.co.uk/ about-us/our-investors/annual-results (accessed on 3 April 2019).

37. Thames Water. Our Leakage Performance. Available online: https://www.thameswater.co.uk/Help-andAdvice/Leaks/our-leakage-performance (accessed on 3 April 2019).

38. Environment Agency. Final Water Resources Planning Guideline. Available online: https://naturalresources. wales/media/678424/ea-nrw-and-defra-wg-ofwat-technical-water-resources-planning-guidelines.pdf (accessed on 3 April 2019).

39. Thames Water. Final Water Resources Management Plan 2015-2040. Available online: https: / / corporate.thameswater.co.uk/-/media/Site-Content/Thames-Water/Corporate/AboutUs/Our-strategiesand-plans/Water-resources/Our-current-plan-WRMP14/WRMP14_Section_9.pdf (accessed on 3 April 2019).

40. Spang, E.S.; Loge, F.J. A high-resolution approach to mapping energy flows through water infrastructure systems. J. Ind. Ecol. 2015, 19, 656-665. [CrossRef]

41. Lam, K.L.; Kenway, S.J.; Lant, P.A. Energy use for water provision in cities. J. Clean. Prod. 2017, 143, 699-709. [CrossRef]

42. Cleveland, R.B.; Cleveland, W.S.; McRae, J.E.; Terpenning, I. STL: A seasonal-trend decomposition. J. Off. Stat. 1990, 6, 3-73.

43. Hyndman, R.J.; Athanasopoulos, G. Forecasting: Principles and Practice; OTexts: Melbourne, Australia, 2018.

44. De Oliveira, E.M.; Oliveira, F.L.C. Forecasting mid-long term electric energy consumption through bagging ARIMA and exponential smoothing methods. Energy 2018, 144, 776-788. [CrossRef]

45. Kenway, S.; Lant, P.; Priestley, A.; Daniels, P. The connection between water and energy in cities: A review. Water Sci. Technol. 2011, 63, 1983-1990. [CrossRef] 
46. Thames Water. Annual Report and Annual Performance Report 2017/18. Available online: https:/ / corporate.thameswater.co.uk/-/media/Site-Content/Thames-Water/Corporate/AboutUs/ Investors / Annual-report/2018/2017-18-Annual-Report-and-Annual-Performance-Report.pdf (accessed on 3 April 2019).

47. UK Water Projects. Thames Gateway Water Treatment Plant: 150,000 $\mathrm{m}^{3} /$ Day Desalination Plant. Available online: http://waterprojectsonline.com/case_studies/2010/Thames_Beckton_2010.pdf (accessed on 15 May 2019).

48. Radcliffe, J.C. The water energy nexus in Australia-The outcome of two crises. Water Energy Nexus 2018, 1,66-85. [CrossRef]

49. Institute of Chemical Engineers. Water Challenges Make UK Desalination Plants More Likely. Available online: https://www.icheme.org/media_centre/news/2013/water-challenges-make-ukdesalination-plants-more-likely.aspx (accessed on 28 March 2019).

50. Ives, M.C.; Simpson, M.; Hall, J.W. Navigating the water trilemma: A strategic assessment of long-term national water resource management options for Great Britain. Water Environ. J. 2018, 32, 546-555. [CrossRef]

51. Colombo, A.F.; Karney, B.W. Impacts of leaks on energy consumption in pumped systems with storage. J. Water Resour. Plan. Manag. 2005, 131, 146-155. [CrossRef]

52. Mourato, S.; Atkinson, G.; Ozdemiroglu, E.; Newcombe, J.; De Garis, Y. Does a cleaner Thames pass an economic appraisal? The value of reducing sewage overflows in the River Thames. Water Int. 2005, 30, 174-183. [CrossRef]

53. Thomas, G.; Crawford, D. London Tideway Tunnels: Tackling London's Victorian legacy of combined sewer overflows. Water Sci. Technol. 2011, 63, 80-87. [CrossRef]

54. Thames Water. Who Will Pay for the Thames Tideway Tunnel? Available online: https://corporate. thameswater.co.uk/about-us/thames-tideway-tunnel/who-will-pay-for-it (accessed on 26 June 2019).

55. National Audit Office. Review of the Thames Tideway Tunnel; Technical Report; DEFRA: London, UK, 2017.

56. Thames Water. What Will Be the Benefits of the Thames Tideway Tunnel? Available online: https:/ / corporate. thameswater.co.uk/about-us/thames-tideway-tunnel/what-are-the-benefits (accessed on 26 June 2019).

57. Discover Water. Greenhouse Gas Emissions from English and Welsh Water Companies. Available online: https:/ / discoverwater.co.uk/energy-emissions (accessed on 14 May 2019).

58. Thames Water. Thames Water: Trunk Main Forensic Review. Available online: https://corporate. thameswater.co.uk/-/media/Site-Content/Thames-Water/Corporate/AboutUs/Investing-in-our-network/ Trunk-mains-review /Thames-Water-Trunk-Mains-Forensic-Review_Final-Findings-Report_FINALpdf.pdf (accessed on 14 May 2019).

59. Venkatesh, G. Cost-benefit analysis-leakage reduction by rehabilitating old water pipelines: Case study of Oslo (Norway). Urban Water J. 2012, 9, 277-286. [CrossRef]

60. Hall, J.W.; Mortazavi-Naeini, M.; Borgomeo, E.; Baker, B.; Gavin, H.; Gough, M.; Harou, J.J.; Hunt, D.; Lambert, C.; Piper, B.; et al. Risk-based water resources planning in practice: A blueprint for the water industry in England. Water Environ. J. 2019. [CrossRef]

(c) 2020 by the authors. Licensee MDPI, Basel, Switzerland. This article is an open access article distributed under the terms and conditions of the Creative Commons Attribution (CC BY) license (http:/ / creativecommons.org/licenses/by/4.0/). 